\title{
PROCALCITONIN, C-REACTIVE PROTEIN AND ERYTHROCYTE SEDIMENTATION RATE IN PERIODIC FEVER, APHTHOUS STOMATITIS, PHARYNGITIS AND CERVICAL ADENITIS (PFAPA SYNDROME)
}

\author{
Cecilia Lazea $^{1}$, Rodica Manasia ${ }^{1}$, Calin Lazar ${ }^{1}$, Laura Damian ${ }^{2}$ \\ ${ }^{1}$ Department Pediatrics I, Emergency Pediatric Hospital, \\ Iuliu Hatieganu University of Medicine and Pharmacy, Cluj-Napoca \\ ${ }^{2}$ Department of Rheumatology, Emergency Clinical County Hospital, Cluj-Napoca
}

\begin{abstract}
Aim. Although PFAPA syndrome is the most common cause of recurrent fever in children, the diagnosis is rarely established and it is a diagnosis of exclusion because there are no specific diagnostic tests. The aim of this study was to assess the value of procalcitonin, C-reactive protein (CRP) and erythrocyte sedimentation rate (ESR) in diagnosis of febrile attacks in PFAPA syndrome.

Material and methods. C-reactive protein, erythrocyte sedimentation rate and procalcitonin were measured in 16 children with PFAPA syndrome during febrile attacks and in 12 children with bacterial pneumonia (control group A) and 18 children with bacterial tonsillitis (control group B).

Results. No significantly statistic differences were recorded for CRP and ESR between the PFAPA group and control groups. Procalcitonin was undetectable in all children with PFAPA syndrome.

Conclusion. Procalcitonin can be a useful marker for differential diagnosis between febrile attacks of PFAPA syndrome and acute bacterial infection in children.
\end{abstract}

Keywords: PFAPA syndrome, procalcitonin, C-reactive protein, erythrocyte sedimentation rate

\section{INTRODUCTION}

PFAPA syndrome (periodic fever, aphthous stomatitis, pharyngitis and cervical adenitis) or Marshall syndrome was described in 1987 by Marshall and it is characterized by recurrent episodes of fever lasting for few days with a recurrence at every 3-8 weeks, with little or no response to common antipyretics, associated with at least one of the three main signs: aphthous stomatitis, cervical adenitis and pharyngitis (1). Patients are asymptomatic between episodes and their growth and development are normal (2-4). Although PFAPA is self-limited and does not cause sequels, the recurrent episodes of fever affect the daily life of the whole family. The etiology is currently not known exactly, but studies on cytokines revealed a significant increase of serum pro-inflammatory cytokine levels during and between the flares and a reduction of anti-inflammatory cytokine levels (5-7). No specific laboratory tests have been identified and the diagnosis is established on clinical criteria and on exclusion of other causes of recurrent fever in children. During flares, acute phase reactants (ESR, CRP and leucocytes) are elevated. Usually procalcitonin does not increase during fever attacks (8-11).

Although PFAPA is the most common cause of recurrent fever in children, the diagnosis is rarely established. This disease is most commonly mistaken as bacterial tonsillitis and these children are given numerous and unnecessary antibiotics. Therefore, the major problem of diagnosis is to differentiate between a PFAPA attack and an infectious febrile disease, especially because there are not specific laboratory tests.

The aim of the present study was to assess the diagnosis value of procalcitonin, $\mathrm{C}$-reactive protein and erythrocyte sedimentation rate in diagnosis of children with PFAPA syndrome in order to make a proper diagnosis and to avoid the unnecessary use of antibiotics.

\section{Correspondence address:}

Cecilia Lazea, MD, Iuliu Hatieganu University of Medicine and Pharmacy, Emergency Pediatric Hospital, 68 Motilor Street, Cluj-Napoca, Romania

E-mail: cicilazearo@yahoo.com,cecilialazea@umfcluj.ro 


\section{PATIENTS AND METHODS}

The study group consisted in 16 children (9 girls and 7 boys, mean age $=4.7$ years), with PFAPA syndrome. Diagnosis of PFAPA syndrome was established according to the Thomas's criteria: regularly recurrent fever with onset in early age, absence of upper respiratory tract infection and at least one of the following clinical signs: pharyngitis, aphthous stomatitis or cervical adenitis. Written, informed consent was obtained from the guardians' participants prior to enrolment into the study. The principles of human research ethics were totally respected.

Data recorded included: medical history of patients and their families, clinical characteristics of febrile episodes and laboratory evaluation (CRP, PCT, ESR, peripheral leukocytes counts, serum immunoglobulins, Epstein-Barr virus serology, urine test). Complete laboratory evaluation has been done in the first 72 hours of the febrile episodes and after 2 weeks from the previous febrile episode.

Other 2 groups of children participated to our study: control group A, which included 12 children ( 6 girls and 6 boys, mean age $=7.1$ years), with bacterial pneumonia and group B, which included 18 children ( 10 girls and 8 boys, mean age $=5.9$ years $)$, with bacterial tonsillitis. For the control groups we obtained the CRP, PCT and ESR levels in the first $24 \mathrm{~h}$ hours from the admission into the hospital, prior to antibiotic treatment. CRP determination were performed using the immunoturbidimetric method and PCT using immunochromatograph method (Siemens Advia 1800 - Immulite 2000XP) and ESR using micro-photometer method (Alifax SIRE Roller 20). Normal reference ranges were: $0-0.8 \mathrm{mg} / \mathrm{dL}$ for CRP, $0-0.5 \mathrm{ng} / \mathrm{dL}$ for procalcitonin and $0-12 \mathrm{~mm} /$ hour for ESR.

Data were statistically analysed using $t$ test.

\section{RESULTS}

Clinical characteristics of PFAPA episodes are presented in Table 1.

Laboratory evaluation of the patients during PFAPA episodes showed elevated values of CRP $(6.1 \pm 3.3 \mathrm{mg} / \mathrm{dL})$ and ESR $(34.1 \pm 13.2 \mathrm{~mm} / \mathrm{h})$. Procalcitonin was undetectable in all patients. All patients had negative serology for Epstein-Barr virus. Quantitative immunoglobulin levels were normal in all children.

Comparison between the PFAPA group and the control groups regarding the value of PCT, CRP and ESR are presented in tables 2 and 3.
TABLE 1. Clinical characteristics of patients with PFAPA syndrome

\begin{tabular}{|c|c|c|}
\hline \multicolumn{2}{|l|}{ Clinical characteristics } & Value \\
\hline \multicolumn{2}{|l|}{ Mean age at onset } & 1.9 years \\
\hline \multicolumn{2}{|l|}{ Mean age at diagnosis } & 4.7 years \\
\hline \multicolumn{2}{|c|}{ Duration of febrile attack } & 3.7 days \\
\hline \multicolumn{2}{|c|}{ Interval between febrile attacks } & 4 weeks \\
\hline \multirow{5}{*}{$\begin{array}{l}\text { Frequency of clinical } \\
\text { symptoms and signs }\end{array}$} & Pharyngitis & $100 \%$ \\
\hline & Cervical adenitis (\%) & $100 \%$ \\
\hline & Aphthous stomatitis (\%) & $62.5 \%$ \\
\hline & Abdominal pain (\%) & $25 \%$ \\
\hline & Skin rash (\%) & $6.25 \%$ \\
\hline
\end{tabular}

TABLE 2. Comparison of CRP, ESR and PCT between PFAPA group and group of children with bacterial pneumonia

\begin{tabular}{|l|l|l|c|c|}
\hline $\begin{array}{l}\text { Para- } \\
\text { meter }\end{array}$ & $\begin{array}{l}\text { PFAPA group } \\
\text { 16 patients }\end{array}$ & $\begin{array}{l}\text { Control group A } \\
\text { (children with } \\
\text { bacterial pneu- } \\
\text { monia) 12 pa- } \\
\text { tients }\end{array}$ & $\mathbf{t}$ & $\mathbf{p}$ \\
\hline CRP & $6.1 \pm 3.3 \mathrm{mg} / \mathrm{dL}$ & $7.7 \pm 4.1 \mathrm{mg} / \mathrm{dL}$ & 0.8654 & 0.399 \\
\hline ESR & $34.1 \pm 13.2 \mathrm{~mm} / \mathrm{h}$ & $\begin{array}{l}39.7 \pm 31.9 \\
\mathrm{~mm} / \mathrm{h}\end{array}$ & 0.4359 & 0.668 \\
\hline PCT & 0 & $0.83 \pm 0.89 \mathrm{ng} / \mathrm{dL}$ & 2.2361 & $\mathbf{0 . 0 4 3}$ \\
\hline
\end{tabular}

TABLE 3. Comparison of CRP, ESR and PCT between PFAPA group and group of children with bacterial tonsillitis

\begin{tabular}{|l|l|l|c|c|}
\hline $\begin{array}{l}\text { Para- } \\
\text { meter }\end{array}$ & $\begin{array}{l}\text { PFAPA group } \\
16 \text { patients }\end{array}$ & $\begin{array}{l}\text { Control group B } \\
\text { (children with } \\
\text { bacterial } \\
\text { tonsillitis) } \\
\mathbf{1 8} \text { patients }\end{array}$ & $\mathbf{t}$ & $\mathbf{p}$ \\
\hline CRP & $6.1 \pm 3.3 \mathrm{mg} / \mathrm{dL}$ & $5.32 \pm 5.00 \mathrm{mg} / \mathrm{dL}$ & 0.3923 & 0.698 \\
\hline ESR & $34.1 \pm 13.2 \mathrm{~mm} / \mathrm{h}$ & $38.6 \pm 19.1 \mathrm{~mm} / \mathrm{h}$ & 0.5407 & 0.596 \\
\hline PCT & 0 & $0.62 \pm 0.94 \mathrm{ng} / \mathrm{dL}$ & 2.3543 & $\mathbf{0 . 0 3 4}$ \\
\hline
\end{tabular}

\section{DISCUSSION}

We reported the clinical and laboratory characteristics of 16 children with PFAPA syndrome. The clinical characteristics of this group showed similar mean duration of the febrile episodes and frequency of episodes with previously reported studies (12-14). We recorded a long period of time (more than 2 years) between the clinical onset and the diagnosis, because the disease is unknown by the family doctors and no specific laboratory tests have been identified.

The increased levels of acute phase reactants (CRP, ESH) during febrile episodes and their normalization between flares has been demonstrated in various studies, but recent studies recorded increased monocytes and decreased eosinophils and mean platelet volume during febrile episodes $(8,15,16)$. However, the mentioned tests are not specific and 
therefore recent studies tried to identify specific laboratory tests. Production of CRP represents a nonspecific acute-phase response to inflammation, infection and tissue damage and has high sensitivity and specificity for the diagnosis of sepsis. CRP rises rapidly, reaching a peak in 2 days $(17,18)$. ESR can be normal at the onset of febrile attack and increases during the flares, so its usefulness as a diagnostic marker is lower than that of CRP (14). In our study, all PFAPA patients had elevated levels of CRP and ESH during flares, but the comparison of CRP and ESR levels of the PFAPA group and the control groups (children with bacterial pneumonia and bacterial tonsillitis) revealed no statistically significant differences.

There are few recent studies which assessed the usefulness of procalcitonin in diagnosis of febrile attacks in PFAPA syndrome (18-20). Procalcitonin, a precursor of calcitonin produced by C-cells of the thyroid gland, the pulmonary neuroendocrine lung cells and possibly other neuroendocrine cells, is released in response to endotoxin and other pro-inflammatory cytokines, such as IL-1 beta, tumour necrosis factor and IL-6, and seems to have deleterious effects in inflammation (21). PCT is a biomarker used in the management of sepsis and infection, as it increases mainly in bacterial infections (18-21). Hence, PCT can help differentiate between bacterial and viral infection, as well as between bacterial and sterile inflammation (18-20). PCT rises very rapidly, during the first 12 hours of beginning of sepsis and has the best sensitivity and negative predictive value (22-24).

Different studies obtained various levels of procalcitonin during febrile attacks, from undetectable levels to slight elevation, suggesting that levels of PCT in PFAPA syndrome are situated between 0.1-0.5 $\mathrm{ng} / \mathrm{dL}(8,9,23)$. In our study, as the laboratory thresh-

\section{REFERENCES}

1. Marshall G.S., Edwards K.M., Butler J. et al. Syndrome of periodic fever, pharyngitis, and aphtous stomatitis. J. Pediatr. 1987; 110:43-46.

2. Thomas K.T., Feder H.M., Lawton A.R. et al. Periodic fever syndrome in children. J. Pediatr. 1999; 135:15-21.

3. Padeh S., Stoffman N., Berkun Y. Periodic Fever Accompanied by Aphthous Stomatitis, Pharyngitis and Cervical Adenitis Syndrome (PFAPA Syndrome) in Adults. IMAJ. 2008; 10:358-360.

4. Cochard M., Clet J., Le L. et al. PFAPA syndrome is not a sporadic disease. Rheumatology. 2010; 49:1984-1987.

5. Stojanov S., Hoffmann F., Kery A. et al. Cytokine profile in PFAPA syndrome suggests continuous inflammation and reduced antiinflammatory response. Eur. Cytokine. Net. 2006; 17(2):90-97.

6. Stojanov S., Lapidus S., Chitkara P. et al. Periodic fever, aphthous stomatitis, pharyngitis, and adenitis (PFAPA) is a disorder old $0.5 \mathrm{ng} / \mathrm{dL}$, all PFAPA patients had undetectable levels of PCT during flares. We obtained statistically significant differences of the PCT levels between the PFAPA group and control groups, as previous studies which indicates that an association of elevated CRP level with an undetectable or normal levels of procalcitonin could be used as diagnosis marker, to distinguish PFAPA attack from a bacterial infection (9-11).

The explanation for the lack of PCT significant elevation currently unknown, but is thought to reflect the disease pathogenesis. Possibly endotoxinemia is a much stronger determinant of PCT when compared to other stimuli $(21,24)$. In viral infections, on the other side, PCT level is normal, as its upregulation is counter-balanced by the release of interferon gamma (20). In other autoinflammatory diseases including familial Mediterranean fever, PCT level, although increased during attack when compared to the patients between the attacks or to normal controls, was generally found to be less than the $0.5 \mathrm{ng} / \mathrm{mL}$ laboratory reference normal values cut-off $(13,25)$. Therefore PCT is usually a good marker to help the differentiation autoinflammatory diseases from bacterial infections. However, in cases of adult onset Still's disease, HIDS/MVK and CINCA/NOMID high values have been occasionally reported $(26,27)$. Of note, in other rheumatologic autoimmune diseases, although generally normal, PCT may be high in Kawasaki syndrome, ANCA-positive vasculitis and Goodpasture syndrome (28).

\section{CONCLUSIONS}

Determination of procalcitonin level in children with PFAPA syndrome can be a useful marker for excluding a bacterial infection. Ultimately, the clinical judgement is decisive in front of a case of fever in a patient with previous autoinflammatory attacks.

of innate immunity and Th1 activation responsive to IL-1 blockade. PNAS. 2011; 108:7148-7153.

7. Kolly L., Busso N., von Scheven-Gete A. et al. Periodic fever, aphthous stomatitis, pharyngitis, cervical adenitis syndrome is linked to dysregulated monocyte IL-1b production. J. Allergy. Clin. Immunol. 2013; 131:1635-1643.

8. Førsvoll J., Øymar K. C-reactive protein in the periodic fever, aphthous stomatitis, pharyngitis and cervical adenitis (PFAPA) syndrome. Acta Paediatrica. 2007; 96:1670-1673.

9. Yoshihara T., Imamura T., Yokoi K. et al. Potential use of procalcitonin concentrations as a diagnostic marker of the PFAPA syndrome. Eur. J. Pediatr. 2007; 166:621-622.

10. Yazgan H., Keles E., Yazgan Z. et al. C-reactive protein and procalcitonin during febril attacks in PFAPA syndrome. Int. J. Ped. Otorhinolaryngol. 2012; 76:1145-1147. 
11. Kraszewska-Głomba B., Szymańska-Toczek Z., Szenborn L. Procalcitonin and C-reactive protein-based decision tree model for distinguishing PFAPA flares from acute infections. Bosn. J. Basic. Med. Sci. 2016; 16:157-161.

12. Tasher D., Stein M., Dalal I. et al. Colchicine prophylaxis for frequent periodic fever, aphthous stomatitis, pharyngitis and adenitis episodes. Acta Paediatrica. 2008; 97:1090-1092.

13. Gattorno M., Caorsi R., Meini A. et al. Differentiating PFAPA Syndrome From Monogenic Periodic Fevers. Pediatrics. 2009; 124:e721-8.

14. Feder H.M., Salazar J.C. A clinical review of 105 patients with PFAPA (a periodic fever syndrome). Acta Paediatrica. 2010; 99:178-184

15. Brown K.L., Wekell P., Osla V. et al. Profile of blood cells and inflammatory mediators in periodic fever, aphthous stomatitis, pharyngitis and adenitis (PFAPA) syndrome. BMC Pediatrics. 2010; 10:65. doi: 10.1186/1471-2431-10-65.

16. Tekin M., Toplu Y., Kahramaner Z. et al. The mean platelet volume levels in children with PFAPA syndrome. Int. J. Pediatr. Otorhinolaryngol. 2014; 78:850-3. doi: 10.1016/j.jporl.2014.02.027.

17. Biron B., Ayala A., Lomas-Neira J. Biomarkers for Sepsis: What Is and What Might Be? Biomarker Insights. 2015:10(S4) 7-17 doi: 10.4137/BMI.S29519

18. Van den Bruel A., Thompson M., Haj-Hassan T. et al. Diagnostic value of laboratory tests in identifying serious infections in febrile children: systematic review. BMJ. 2011; 342:d3082. doi:10.1136/ bmj.d3082.

19. Maruna P., Nedělníkóvá K., Gürlich R. Phsiology and genetics of procalcitonin. Phsiol. Res. 2000; 49(Suppl 1):S57-S61.

20. Schuetz P., Albrich W., Mueller B. Procalcitonin for diagnosis of infection and guide to antibiotic decisions: past, present and future. BMC. Med. 2011:9:107. doi: 10.1186/1741-7015-9-107.
21. Becker K.L., Snider R., Nylen E.S. Procalcitonin in sepsis and systemic inflammation: a harmful biomarker and a therapeutic target. Br J Pharmacol 2010; 159(2):253-64.

22. Galetto-Lacour A., Zamora S.A., Gervaix A. Bedside procalcitonin and C-reactive protein tests in children with fever without localizing signs of infection seen in a referral center. Pediatrics. 2003;112:1054-60.

23. Andreola B., Bressan S., Callegaro S. et al. Procalcitonin and $\mathrm{C}$-reactive protein as diagnostic markers of severe bacterial infections in febrile infants and children in the emergency department. Pediatr. Infect. Dis. J. 2007; 26:672-677.

24. Førsvoll J., Kristoffersen E.K., Øymar K. Is There a Role for Procalcitonin in the Evaluation of Children with PFAPA Syndrome? Ann. Paediatr. Rheum. 2012; 3:171-175. DOI: 10.5455/ apr.092520121447

25. Yuksel S., Ekim M., Ozcakar Z.B. et al. The value of procalcitonin measurement in children with familial Mediterranean fever. Rheumatol. Int. 2012; 32:3443-3447.

26. Simon A., Bijzet J., Voorbij H.A.M. et al. Effect of inflammatory attacks in the classical type hyper-lgD syndrome on immunoglobulin $\mathrm{D}$, cholesterol and parameters of the acute phase response. J. Internal. Med. 2004;256:247-253. doi:10.1111/j.13652796.2004.01359.x

27. Kanariou M., Tantou S., Varela I. et al. Successful management of cryopyrin-associated periodic syndrome with canakinumab in infancy. Pediatrics. 2014; 134(5):e1468-73. doi:10.1542/peds.20133185.

28. Meisner M. Update on procalcitonin measurements. Ann. Lab. Med. 2014; 34(4):263-273. 